\title{
ANTAGONISM OF $\alpha_{2 A}$-ADRENOCEPTOR: A NOVEL APPROACH TO INHIBIT INFLAMMATORY RESPONSES IN SEPSIS
}

\author{
Fangming Zhang, Rongqian Wu, Xiaoling Qiang, Mian Zhou, and Ping Wang \\ The Feinstein Institute for Medical Research Manhasset, NY 11030 \\ Department of Surgery North Shore University Hospital and Long Island Jewish Medical Center \\ Manhasset, NY 11030
}

\section{Abstract}

Sepsis is a systemic inflammatory response syndrome (SIRS) when an infection is the etiology of SIRS. Our previous studies have indicated that the release of the sympathetic neurotransmitter, norepinephrine (NE), from the gut is increased in sepsis, and that NE potentiates endotoxininduced TNF- $\alpha$ upregulation via the A subtype of $\alpha_{2}$-adrenoceptors (i.e., $\alpha_{2 A}$-AR) expressed on the surface of Kupffer cells. A specific antagonist for $\alpha_{2 \mathrm{~A}}$-AR, 2-[(4,5-dihydro-1H-imidazol-2-yl) methyl]-2,3-dihydro-1-methyl-1H-isoindole maleate (BRL-44408 maleate), reduces TNF- $\alpha$ secretion in cultured Kupffer cells. We, therefore, hypothesize that administration of BRL-44408 malaete inhibits inflammatory responses and reduces organ injury in sepsis. To study this, sepsis was induced in male rats by cecal ligation and puncture (CLP). At $5 \mathrm{~h}$ after CLP, BRL-44408 maleate $(0.3125,0.625,1.25,2.5$, or $5.0 \mathrm{mg} / \mathrm{kg} \mathrm{BW})$ or vehicle (1-ml normal saline) were administered intravenously over a period of $30 \mathrm{~min}$. Blood and intestinal samples were collected at $20 \mathrm{~h}$ after CLP. Serum levels of TNF- $\alpha$, IL-6, IL-10, keratinocyte-derived chemokine (KC), macrophage inflammatory protein-2 (MIP-2), liver enzymes (i.e., AST and ALT), and lactate were measured. The intestinal levels of TNF- $\alpha$, IL- 6 and myeloperoxidase (MPO) activities were also analyzed. In additional groups of animals, the necrotic cecum was excised at $20 \mathrm{~h}$ post-CLP and the 10-day survival was recorded. Our results showed that serum levels of pro-inflammatory cytokines (TNF- $\alpha$ and IL-6), anti-inflammatory cytokine (IL-10), chemokines (KC, MIP-2), liver enzymes (AST and ALT), lactate and intestinal levels of TNF- $\alpha$, IL-6 and MPO were significantly elevated at $20 \mathrm{~h}$ after CLP. Administration of BRL-44408 maleate significantly reduced serum levels of pro-inflammatory cytokines, chemokines, liver enzymes and lactate, and dramatically decreased TNF- $\alpha$, IL- 6 and MPO levels in the gut. However, it has no statistical effects on the elevated serum levels of IL-10. Moreover, BRL-44408 maleate at the doses of 2.5 or $5.0 \mathrm{mg} / \mathrm{kg}$ BW significantly increased the survival rate after CLP and cecal excision. In conclusion, modulation of the sympathetic nervous system by blocking $\alpha_{2 \mathrm{~A}}$-AR appears to be a novel treatment for inflammatory conditions such as sepsis.

\section{Keywords}

Sepsis; $\alpha_{2 \mathrm{~A}}$-adrenoceptor; inflammation; survival

Please address correspondence, proofs, and reprint requests to: Ping Wang, M.D. Laboratory of Surgical Research The Feinstein Institute for Medical Research 350 Community Drive Manhasset, NY 11030 Tel: (516) 562-3411 Fax: (516) 562-1022 pwang@nshs.edu. 


\section{INTRODUCTION}

Despite the increased understanding of the complex pathophysiology of sepsis and the discovery of new treatments, severe sepsis still results in significant morbidity and mortality [1-4]. Evidence indicates that in the US alone, more than 750,000 people develop sepsis each year with an overall mortality of $28.6 \%$ [5]. A recent analysis of hospital records indicates that the total number of patients who have died of sepsis is actually increasing [2]. As the American population ages, it is anticipated that the occurrence of sepsis and subsequent mortality will significantly increase. Although activated protein C [APC, Drotrecogin alpha (activated), Xigris ${ }^{\circledR}$, marketed by Eli Lilly] is the only FDA-approved specific treatment for sepsis, it cannot be used in patients at risk for bleeding, in infants, and in immunosuppressed patients, especially those with thrombocytopenia or neutropenia, due to its adverse effects on coagulation [1,6]. Moreover, even in the highly selected septic patients, APC only provides a relatively modest survival benefit [6]. As such, there is an urgent unmet medical need for an effective novel therapy for septic patients.

Our previous studies have demonstrated that the release of the sympathetic neurotransmitter, norepinephrine (NE) from the gut, is increased in sepsis [7], and that inhibition of the sympathetic nervous activity is beneficial in a rat model of polymicrobial sepsis [8]. NE potentiates endotoxin-induced tumor necrosis factor (TNF)- $\alpha$ upregulation via the A subtype of $\alpha_{2}$-adrenoceptors (i.e., $\alpha_{2 \mathrm{~A}}$-AR) expressed on the surface of Kupffer cells [9]. In cultured Kupffer cells, NE increases the release of TNF- $\alpha$ and a specific $\alpha_{2 \mathrm{~A}}$-AR antagonist, 2-[(4,5dihydro-1H-imidazol-2-yl) methyl]-2,3-dihydro-1-methyl-1H-isoindole maleate (BRL-44408 maleate), a specific $\alpha_{2 \mathrm{~A}}$-AR antagonist [10], reduces TNF- $\alpha$ secretion [9]. However, it remains unknown whether administration of BRL-44408 maleate after the onset of sepsis (i.e., post-treatment) reduces sepsis-induced organ dysfunction in rats. This study was conducted to test the hypothesis that delayed administration of BRL-44408 malaete inhibits inflammatory responses and reduces organ injury in sepsis.

\section{MATERIALS AND METHODS}

\section{Animal model of sepsis}

Male Sprague-Dawley rats (275-375g) were housed in a temperature-controlled room on a 12-h light/dark cycle and fed a standard Purina rat chow diet. Prior to the induction of sepsis, rats were fasted overnight, but allowed water ad libitum. Rats were anesthetized with isoflurane inhalation and the ventral neck, abdomen and groin were shaved and washed with $10 \%$ povidone iodine. Cecal ligation and puncture (CLP) was performed as we previously described [11-13]. Briefly, a 2-cm midline abdominal incision was performed. The cecum was exposed, ligated just distal to the ileocecal valve to avoid intestinal obstruction, punctured twice with an 18-gauge needle, squeezed slightly to allow a small amount of fecal matter to flow from the holes, and then returned to the abdominal cavity, following which the abdominal incision was closed in layers. Sham-operated animals (i.e., control animals) underwent the same procedure with the exception that the cecum was neither ligated nor punctured. The animals were resuscitated with $3 \mathrm{ml} / 100 \mathrm{~g}$ BW normal saline subcutaneously immediately after surgery. The animals were then returned to their cages. All experiments were performed in accordance with the National Institutes of Health guidelines for the use of experimental animals. This project was approved by the Institutional Animal Care and Use Committee (IACUC) of the Feinstein Institute for Medical Research.

\section{Administration of BRL-44408 maleate}

At $5 \mathrm{~h}$ after CLP, the left femoral vein was cannulated with a polyethylene-50 tubing under isoflurane anesthesia. Various doses of BRL-44408 maleate $(0.3125,0.625,1.25,2.5$, or 5.0 
$\mathrm{mg} / \mathrm{kg}$ BW; Tocris Bioscience, Ellisville, MO) in a volume of 1-ml normal saline or 1-ml normal saline (vehicle) were administered intravenously via the femoral catheter over 30 $\mathrm{min}$ at a constant infusion rate. Blood samples were collected at $20 \mathrm{~h}$ after sham operation or CLP and placed on ice to allow clotting. The samples were then centrifuged at $1200 \mathrm{~g}$ for 10 $\min$ at $4^{\circ} \mathrm{C}$, and the serum samples were stored at $-80^{\circ} \mathrm{C}$ until assayed. A $\sim 5 \mathrm{~cm}$ long jejunal segment was harvested from each animal at $20 \mathrm{~h}$ after CLP or sham operation and stored at $-80^{\circ} \mathrm{C}$ until assayed.

\section{Determination of tumor necrosis factor (TNF)- $\alpha$, interleukins (IL)-6, IL-10, keratinocyte- derived chemokine (KC) and macrophage inflammatory protein (MIP)-2}

The intestinal samples were excised, rinsed of blood, homogenized with polytron in an icecold lysis buffer (1\% Triton X-100 in TBS with protease inhibitors, $\mathrm{pH}, 7.5)$ and sonicated 30 seconds on ice. The tissue lysates were centrifuged at 12,000 rpm for $10 \mathrm{~min}$ and protein concentration was measured by using Bio-Rad DC Protein Assay Kit (Bio-Rad, Hercules, CA). TNF- $\alpha$ and IL-6 in the gut and serum were quantified with the use of specific enzyme linked immunosorbent assay (ELISA) kits according to the instructions provided by the manufacturer (BD Biosciences Pharmingen, San Diego, CA). Intestinal levels of TNF- $\alpha$ and IL-6 were normalized to the protein concentration in the sample. Serum levels of IL-10, KC and MIP-2 were measured using rat IL-10 ELISA kit (BD Biosciences Pharmingen), Quantikine KC ELISA kit (R\&D Systems, Minneapolis, MN) and MIP-2 ELISA kit (ALPCO Diagnostics, Salem, NH), respectively, as per the manufacturers' instructions.

\section{Measurement of myeloperoxidase (MPO) activity}

Neutrophil accumulation in the gut was estimated using the MPO activity assay as we described previously [14]. Briefly, samples of $100 \mathrm{mg}$ were suspended in $1 \mathrm{ml}$ of $0.5 \%$ hexadecyltrimethylammonium bromide in $50 \mathrm{mmol} / \mathrm{L}$ phosphate buffer $(\mathrm{pH} 6.0)$ and sonicated 90 seconds on ice. Homogenates were cleared by centrifuging at 12,000 rpm for $10 \mathrm{~min}$ at $4{ }^{\circ} \mathrm{C}$, and the protein concentration of supernatants was determined by using BioRad DC Protein Assay Kit (Bio-Rad, Hercules, CA). The reaction was carried out in a 96well plate by adding $290 \mu \mathrm{l}$ of $50 \mathrm{mmol} / \mathrm{L}$ phosphate buffer with $3 \mu \mathrm{l}$ substrate solution (containing $20 \mathrm{mg} / \mathrm{ml}$ o-dianisidine hydrochloride), and $3 \mu \mathrm{H}_{2} \mathrm{O}_{2}(20 \mathrm{mmol} / \mathrm{L})$. Sample (10 $\mu \mathrm{l})$ was added to each well to start the reaction. Plates were read spectrophotometrically at $460 \mathrm{~nm}$ for 3 min on CERES UV 900C Microplate reader (Bio-Tek Inst Inc, Winooski, VT). MPO activity (1 unit defined as change in absorbance of 1 per min) was expressed as units per gram of tissue.

\section{Determination of serum levels of transaminases and lactate}

Serum concentrations of alanine aminotransferase (ALT), aspartate aminotransferase (AST) and lactate were determined by using assay kits according to the manufacturer's instructions (Pointe Scientific, Inc. Canton, MI).

\section{Survival study}

In additional groups of animals, various doses of BRL-44408 maleate $(1.25,2.5$, or $5.0 \mathrm{mg}$ / $\mathrm{kg}$ ) in a volume of $1-\mathrm{ml}$ normal saline or $1 \mathrm{ml}$-normal saline (vehicle) were administered as described above at $5 \mathrm{~h}$ after CLP. At $20 \mathrm{~h}$ after CLP, the necrotic cecum was excised and the abdominal cavity was washed twice with $40 \mathrm{ml}$ of warm, sterilized normal saline solution. The abdominal incision was closed in layers. The procedure of cecal excision in CLP animals was performed to mimic the clinical situation in which septic focus is removed whenever possible. The animals then were allowed food and water ad libitum. All surviving animals were sacrificed on Day 10. 


\section{Statistical analysis}

All data are expressed as means \pm SE, with $n=6$ animals per group and compared by oneway analysis of variance (ANOVA) and Student-Newman-Keuls method. The survival rate, with $n=20$ animals, was estimated by Kaplan-Meier method and compared by the log-rank test. Differences in values were considered significant if $\mathrm{P}<0.05$.

\section{RESULTS}

\section{BRL-44408 maleate downregulates proinflammatory cytokines after CLP}

As indicated in Figure 1A, serum levels of TNF- $\alpha$ increased by 14-fold at $20 \mathrm{~h}$ after CLP $(\mathrm{P}<0.05)$. All three doses of BRL-44408 maleate treatment decreased serum TNF- $\alpha$ levels by over $60 \%(\mathrm{P}<0.05)$. Similarly, circulating levels of IL-6 increased by 71 -fold at $20 \mathrm{~h}$ after CLP; BRL-44408 maleate treatment significantly reduced IL-6 levels in a dose dependent manner $(\mathrm{P}<0.05$, Fig. 1B). As shown in Figures $2 \mathrm{~A}-\mathrm{B}$, intestinal levels of TNF- $\alpha$ and IL-6 increased by 8.9 fold and 4.3 fold, respectively, at $20 \mathrm{~h}$ after CLP $(\mathrm{P}<0.05)$. Administration of all three doses of BRL-44408 maleate decreased intestinal TNF- $\alpha$ levels significantly $(\mathrm{P}<0.05$, Fig. 2A). However, the effects of BRL-44408 maleate on intestinal TNF- $\alpha$ levels are not in a clear dose-dependent manner. Administration of 1.25 or $2.5 \mathrm{mg} / \mathrm{kg} \mathrm{BW}$ BRL-44408 maleate decreased intestinal IL-6 levels by 39 and 35\%, respectively. However, these decreases were not statistically significant. When $5.0 \mathrm{mg} / \mathrm{kg}$ BW BRL-44408 maleate was administered, intestinal IL-6 levels were significantly reduced by $68 \%(\mathrm{P}<0.05$, Fig. 2B).

\section{BRL-44408 maleate reduces serum chemokine levels and neutrophil infiltration in the gut after CLP}

As shown in Figures 3A-B, dramatic increases in serum levels of KC and MIP-2 were observed at $20 \mathrm{~h}$ after CLP $(\mathrm{P}<0.05)$. Administration of all three doses of BRL-44408 maleate decreased serum KC and MIP-2 levels by over $65 \%$. However, the effects of BRL-44408 maleate on chemokine levels are not in a clear dose-dependent manner. The level of MPO activity is an indicator of neutrophil infiltration. As demonstrated in Figure 4, intestinal levels of MPO activities increased significantly at $20 \mathrm{~h}$ after CLP. Treatment with BRL-44408 maleate inhibited the increase in intestinal MPO activities after CLP $(\mathrm{P}<0.05)$. Since the correlation of chemokine levels and MPO levels has been very well established [15], we did not perform such an analysis in this study.

\section{BRL-44408 maleate has no effect on anti-inflammatory cytokine IL-10 after CLP}

As indicated in Figure 5, serum levels of IL-10 increased by 10.7-fold at $20 \mathrm{~h}$ after CLP $(\mathrm{P}<0.05)$. Administration of BRL-44408 maleate had no significant effects on the elevated serum levels of IL-10.

\section{BRL-44408 maleate attenuates organ injury after CLP}

Consistent with previous studies [13], significant increases in liver enzymes (ALT, AST) were observed at $20 \mathrm{~h}$ after CLP (Figs. 6A-B), indicating hepatic injury. All three doses of BRL-44408 maleate treatment significantly attenuated the increased levels of ALT. Administration of 1.25 or $2.5 \mathrm{mg} / \mathrm{kg}$ BW BRL-44408 maleate decreased AST levels by $30 \%$ and $37 \%$, respectively. However, these decreases were not statistically significant. When 5.0 $\mathrm{mg} / \mathrm{kg}$ BW BRL-44408 maleate was administered, serum AST levels were significantly reduced by $51 \%$ ( $\mathrm{P}<0.05$, Fig. 6B). Serum levels of lactate, a marker for systemic hypoxia, increased by $358 \%$ at $20 \mathrm{~h}$ after CLP and administration of BRL-44408 maleate decreased lactate levels ( $\mathrm{P}<0.05$, Fig. $5 \mathrm{C})$. 


\section{Effects of lower doses of BRL-44408 maleate on inflammatory responses and organ injury after CLP}

As showed above, the beneficial effect of BRL-44408 maleate in sepsis is not dosedependent. To determine the effect of lower doses of BRL-44408 maleate in sepsis, 0.3125 or $0.625 \mathrm{mg} / \mathrm{kg}$ BW BRL-44408 maleate was administered at $5 \mathrm{~h}$ after CLP. Blood and gut samples were collected at $20 \mathrm{~h}$ after CLP for various measurements. As shown in Table 1, administration of 0.3125 or $0.625 \mathrm{mg} / \mathrm{kg} \mathrm{BRL}-44408$ is not as effective as administration of $1.25 \mathrm{mg} / \mathrm{kg}$ BRL-44408 or higher doses in this rat model of sepsis.

\section{BRL-44408 maleate improves survival after CLP}

It is almost impossible to fully confirm the beneficial effect of BRL-44408 maleate without the assessment of each organ system. However, it is practically impossible to do so in a single study. In such, we have conducted the survival study to determine the systemic and long-term beneficial effect of BRL-44408 maleate in sepsis. As shown in Figure 7, the survival rate after CLP and cecal excision in vehicle treated animals was $60 \%$ at day 3 , and decreased to $45 \%$ at days $4-10$. Administration of $1.25 \mathrm{mg} / \mathrm{kg}$ of BRL 44408 maleate improved the survival rate to $60 \%$. However, this increase was not statistically significant. When 2.5 or $5.0 \mathrm{mg} / \mathrm{kg}$ BW BRL-44408 maleate was administered, the survival rates were significantly increased to $85 \%$ and $80 \%$, respectively ( $\mathrm{P}<0.05$, Fig. 7 ).

\section{DISCUSSION}

An appropriate inflammatory response eliminates the invading micro-organisms without causing damage to tissues, organs, or other systems. However, excessive and sustained inflammatory responses can lead to severe tissue damage. Overproduction of proinflammatory cytokines (e.g., TNF- $\alpha$ and IL-6) $[16,17]$ and chemokines (e.g., KC and MIP-2) $[15,18]$ have been implicated to play an important role in producing organ dysfunction in sepsis. Physicians and scientists have therefore focused on the elimination of the potentially detrimental pro-inflammatory mediators. In the past, various efforts have been made to inhibit cytokines such as TNF- $\alpha$ in septic patients by utilizing antibodies or soluble receptors. Unfortunately, the results have been generally disappointing and interspersed with some spectacular failures and unexpected toxicities [19]. The failed clinical trials may be caused by the possibility that the complete elimination of inflammatory cytokines is detrimental. In the present study, we demonstrate a novel approach to treat sepsis: to modulate proinflammatory mediators, but not directly block them, by the use of the $\alpha_{2 \mathrm{~A}}$-adrenoceptor antagonist. As such, our strategy represents an innovative approach in the field of preclinical development of anti-sepsis drugs. Using a rat model of polymicrobial sepsis, we clearly demonstrate the beneficial effect of a specific $\alpha_{2 \mathrm{~A}}$-AR antagonist, BRL-44408 maleate, in sepsis.

The interaction between the central nervous system and immune system under various inflammatory diseases has found considerable interest in the past few decades. It is now widely accepted that the vagus nerve can inhibit the proinflammatory response [20,21]. However, sympathetic influence on immune function is far more complicated. The adrenergic effects of the sympathetic nervous system are mediated through nine different adrenoceptors: three $\alpha_{1}$ receptors $\left(\alpha_{1 \mathrm{~A}}, \alpha_{1 \mathrm{~B}}, \alpha_{1 \mathrm{C}}\right)$, three $\alpha_{2}$ receptors $\left(\alpha_{2 \mathrm{~A}}, \alpha_{2 \mathrm{~B}}, \alpha_{2 \mathrm{C}}\right)$, and three $\beta$ receptors $\left(\beta_{1}, \beta_{2}, \beta_{3}\right)$. Catecholamines possess both antiinflammatory and proinflammatory activities. The adrenergic antiinflammatory effects are mostly mediated by $\beta_{2}$-adrenoceptors [22,23]; whereas stimulation of $\alpha_{2}$-adrenoceptors by $\alpha_{2}$-adrenergic agonists shows proinflammatory effects [24]. Only supraphysioliogic levels of NE can inhibit cytokine release from monocytes/macrophages [9]. Many studies focusing on the immunomodulation by NE used high concentrations of NE (i.e., $10^{-4} \mathrm{M}$ ) and thus were 
more likely to activate $\beta_{2}$-receptors that override $\alpha_{2}$-receptor-mediated proinflammatory responses [25-27]. Our previous studies have shown that intraportal injection of NE, at concentrations found under septic conditions $(\sim 20 \mathrm{nM})$, produced an increase of circulating levels of proinflammatory cytokines (e.g., TNF- $\alpha$ and IL-6), similar to that found in sepsis $[24,28,29]$. This dose of NE (i.e., $20 \mathrm{nM}$ ) did not alter cardiac output [29], suggesting that the NE concentration in the circulation was low enough not to influence $\beta$-receptor-mediated cardiac performance. This further implies that $\alpha_{2}$-adrenoceptors on Kupffer cells/ macrophages become selectively activated in sepsis [23]. Through in vitro experiments with selective $\alpha$-adrenergic inhibitors, we later found that the $\alpha_{2 \mathrm{~A}}$-AR subtype on Kupffer cells is responsible for the increased cytokine release [9]. Moreover, the receptor distribution pattern on Kupffer cells changes during the course of sepsis by increasing pro-inflammatory $\alpha_{2 A^{-}}$ AR expression while showing no changes in the expression of the other two $\alpha_{2}$-AR subtypes $\alpha_{2 B}$ and $\alpha_{2 C}$ [9]. Thus, these highly specialized macrophages express a different pattern of adrenoceptors and display a differential response to catecholamines, which drives the noradrenergic effect towards a systemic proinflammatory response. The result that systemic application of the $\alpha_{2 A}$-AR inhibitor BRL-44408 maleate inhibited the pro-inflammatory response in sepsis, further confirms this concept. Since elevated levels of proinflammatory cytokines (e.g., TNF- $\alpha$ and IL-6) and chemokines inhibit cardiac function [30,31], damage the liver [16,17], and potentiate lung injury [32], we believe that downregulation of proinflammatory responses (in a non-IL-10 dependent manner) plays an important role in the beneficial effect of BRL-44408 in sepsis. Our previous study has shown that prior reduction of Kupffer cell numbers, through the use of gadolinium chloride, prevents the increase in plasma levels of proinflammatory cytokines and the occurrence of cell dysfunction in sepsis [33]. However, the data in this manuscript can not prove that the beneficial effect of BRL-44408 maleate is primarily mediated through Kupffer cells.

Human sepsis is usually caused by a nidus of infection with replicating bacteria (e.g., pneumonia or intra-abdominal abscess) that persists for an extended time. A wide variety of animal models have been developed to simulate human sepsis in order to reduce the covariate factors inherent in human investigations. In this study, we have utilized the rat model of CLP to produce polymicrobial sepsis. This model of sepsis is considered to be clinically relevant since it mimics many features of clinical peritonitis-sepsis. It is associated with an early, hyperdynamic phase (i.e., 2-10 h after CLP; characterized by an increased cardiac output and tissue perfusion, decreased vascular resistance, and hyperglycemia), which is followed by a late, hypodynamic phase ( $16 \mathrm{~h}$ after CLP and later; characterized by reduced cardiac output and tissue perfusion, increased vascular resistance, and hypoglycemia) $[16,34,35]$. We chose to treat septic rats at $5 \mathrm{~h}$ after CLP, because proinflammatory cytokines such as TNF- $\alpha$ and IL-6 increase significantly at $5 \mathrm{~h}$ after CLP [36]. Since severe sepsis occurred at $20 \mathrm{~h}$ post-CLP [34,35], we shoes this time point to assess organ injury. In the current study, we have investigated the dose-dependent effect of BRL-44408 maleate using the rat CLP model of sepsis. Although not all the parameters were improved in a dose-dependent manner, the higher dose groups seem to show better protection than the lower dose group. Most importantly, administration of less than $1.25 \mathrm{mg}$ / $\mathrm{kg}$ BW BRL-44408 maleate at $5 \mathrm{~h}$ after CLP failed to significantly inhibit inflammatory responses. It appears that $2.5 \mathrm{mg} / \mathrm{kg} \mathrm{BW}$ or higher doses of BRL-44408 maleate are required to improve survival in sepsis. Although the optimal dose of BRL-44408 maleate could not be fully established using the rat model of sepsis, the dose of $2.5 \mathrm{mg} / \mathrm{kg} \mathrm{BW}$ produced the best survival protection. In the future, we will also verify these findings using other models of sepsis and determine the therapeutic window of this compound under such conditions. To advance this project into clinical trials, the full-scale pharmacokinetic as well as toxicological properties of BRL-44408 maleate will also be investigated. 
In summary, a proinflammatory state and severe tissue injury were present at $20 \mathrm{~h}$ after CLP. Administration of BRL-44408 maleate, a specific $\alpha_{2 \mathrm{~A}}$-AR antagonist, at $5 \mathrm{~h}$ after CLP not only inhibited the proinflammatory response, but also attenuated tissue injury and improved survival. Thus, modulation of the sympathetic nervous system by blocking $\alpha_{2 A^{-}}$ AR appears to be a novel treatment for sepsis and septic shock. We believe that the current study is an important step towards further development of BRL-44408 maleate as a novel therapeutic approach for patients with sepsis.

\section{Acknowledgments}

This study was partially supported in part by National Institutes of Health grant R01 GM053008 (PW).

\section{Abbreviations}

$\begin{array}{ll}\text { NE } & \text { norepinephrine } \\ \boldsymbol{\alpha}_{2 \mathbf{A}}-\mathbf{A R} & \text { A subtype of } \alpha_{2} \text {-adrenoceptors } \\ \text { TNF- } \alpha & \text { tumor necrosis factor- } \alpha \\ \text { BRL-44408 maleate } & \begin{array}{l}\text { 2-[(4,5-dihydro-1H-imidazol-2-yl) methyl]-2,3-dihydro-1- } \\ \text { methyl-1H-isoindole maleate } \\ \end{array} \\ \text { cLP } & \text { kecal ligation and puncture } \\ \text { KC } & \text { macrophage inflammatory protein-2 } \\ \text { MIP-2 } & \text { myeloperoxidase }\end{array}$

\section{REFERENCES}

1. Bernard GR, Vincent JL, Laterre PF, LaRosa SP, Dhainaut JF, Lopez-Rodriguez A, Steingrub JS, Garber GE, Helterbrand JD, Ely EW, Fisher CJ Jr. Efficacy and safety of recombinant human activated protein C for severe sepsis. N Engl J Med. 2001; 344:699-709. [PubMed: 11236773]

2. Martin GS, Mannino DM, Eaton S, Moss M. The epidemiology of sepsis in the United States from 1979 through 2000. N Engl J Med. 2003; 348:1546-1554. [PubMed: 12700374]

3. Danai PA, Sinha S, Moss M, Haber MJ, Martin GS. Seasonal variation in the epidemiology of sepsis. Crit Care Med. 2007; 35:410-415. [PubMed: 17167351]

4. Strehlow MC, Emond SD, Shapiro NI, Pelletier AJ, Camargo CA Jr. National study of emergency department visits for sepsis, 1992 to 2001. Ann Emerg Med. 2006; 48:326-331. [PubMed: 16934654]

5. Angus DC, Linde-Zwirble WT, Lidicker J, Clermont G, Carcillo J, Pinsky MR. Epidemiology of severe sepsis in the United States: analysis of incidence, outcome, and associated costs of care. Crit Care Med. 2001; 29:1303-1310. [PubMed: 11445675]

6. Friedrich JO, Adhikari NK, Meade MO. Drotrecogin alfa (activated): does current evidence support treatment for any patients with severe sepsis? Crit Care. 2006; 10:145. [PubMed: 16762040]

7. Hahn PY, Wang P, Tait SM, Ba ZF, Reich SS, Chaudry IH. Sustained elevation in circulating catecholamine levels during polymicrobial sepsis. Shock. 1995; 4:269-273. [PubMed: 8564555]

8. Wu R, Zhou M, Das P, Dong W, Ji Y, Yang D, Miksa M, Zhang F, Ravikumar TS, Wang P. Ghrelin inhibits sympathetic nervous activity in sepsis. Am J Physiol Endocrinol Metab. 2007; 293:E1697E1702. [PubMed: 17911350]

9. Miksa M, Wu R, Zhou M, Wang P. Sympathetic excitotoxicity in sepsis: pro-inflammatory priming of macrophages by norepinephrine. Front Biosci. 2005; 10:2217-2229. [PubMed: 15970488]

10. Stone LS, Kitto KF, Eisenach JC, Fairbanks CA, Wilcox GL. ST91 [2-(2,6-diethylphenylamino)-2imidazoline hydrochloride]-mediated spinal antinociception and synergy with opioids persists in 
the absence of functional alpha-2A- or alpha-2Cadrenergic receptors. J Pharmacol Exp Ther. 2007; 323:899-906. [PubMed: 17855473]

11. Wu R, Dong W, Zhou M, Zhang F, Marini CP, Ravikumar TS, Wang P. Ghrelin attenuates sepsisinduced acute lung injury and mortality in rats. Am J Respir Crit Care Med. 2007; 176:805-813. [PubMed: 17626913]

12. Cui X, Wu R, Zhou M, Simms HH, Wang P. Differential expression of cytochrome P450 isoforms in the lungs of septic animals. Crit Care Med. 2004; 32:1186-1191. [PubMed: 15190971]

13. Wu R, Dong W, Cui X, Zhou M, Simms HH, Ravikumar TS, Wang P. Ghrelin down-regulates proinflammatory cytokines in sepsis through activation of the vagus nerve. Ann Surg. 2007; 245:480-486. [PubMed: 17435556]

14. Dwivedi AJ, Wu R, Nguyen E, Higuchi S, Wang H, Krishnasastry K, Marini CP, Ravikumar TS, Wang P. Adrenomedullin and adrenomedullin binding protein-1 prevent acute lung injury after gut ischemia-reperfusion. J Am Coll Surg. 2007; 205:284-293. [PubMed: 17660075]

15. Luster AD. Chemokines--chemotactic cytokines that mediate inflammation. N Engl J Med. 1998; 338:436-445. [PubMed: 9459648]

16. Wang P, Chaudry IH. Mechanism of hepatocellular dysfunction during hyperdynamic sepsis. Am J Physiol. 1996; 270:R927-R938. [PubMed: 8928923]

17. Wang P, Ba ZF, Chaudry IH. Mechanism of hepatocellular dysfunction during early sepsis: key role of increased gene expression and release of proinflammatory cytokines tumor necrosis factor and interleukin-6. Arch Surg. 1997; 132:364-370. [PubMed: 9108756]

18. Hotchkiss RS, Karl IE. The Pathophysiology and Treatment of Sepsis. N Engl J Med. 2003; 348:138-150. [PubMed: 12519925]

19. Riedemann NC, Guo RF, Ward PA. Novel strategies for the treatment of sepsis. Nat Med. 2003; 9:517-524. [PubMed: 12724763]

20. Tracey KJ. The inflammatory reflex. Nature. 2002; 420:853-859. [PubMed: 12490958]

21. Tracey KJ. Physiology and immunology of the cholinergic antiinflammatory pathway. J Clin Invest. 2007; 117:289-296. [PubMed: 17273548]

22. Elenkov IJ, Wilder RL, Chrousos GP, Vizi ES. The sympathetic nerve--an integrative interface between two supersystems: the brain and the immune system. Pharmacol Rev. 2000; 52:595-638. [PubMed: 11121511]

23. Vizi ES, Elenkov IJ. Nonsynaptic noradrenaline release in neuro-immune responses. Acta Biol Hung. 2002; 53:229-44. [PubMed: 12064774]

24. Zhou M, Yang S, Koo DJ, Ornan DA, Chaudry IH, Wang P. The role of Kupffer cell alpha(2)adrenoceptors in norepinephrine-induced TNF-alpha production. Biochim Biophys Acta. 2001; 1537:49-57. [PubMed: 11476962]

25. Elenkov IJ, Papanicolaou DA, Wilder RL, Chrousos GP. Modulatory effects of glucocorticoids and catecholamines on human interleukin-12 and interleukin-10 production: clinical implications. Proc Assoc Am Physicians. 1996; 108:374-81. [PubMed: 8902882]

26. Hasko G, Szabo C. Regulation of cytokine and chemokine production by transmitters and cotransmitters of the autonomic nervous system. Biochem Pharmacol. 1998; 56:1079-1087. [PubMed: 9802316]

27. Severn A, Rapson NT, Hunter CA, Liew FY. Regulation of tumor necrosis factor production by adrenaline and $\beta$-adrenergic agonists. J Immunol. 1992; 148:3441-3445. [PubMed: 1350291]

28. Yang S, Koo DJ, Zhou M, Chaudry IH, Wang P. Gut-derived norepinephrine plays a critical role in producing hepatocellular dysfunction during early sepsis. Am J Physiol Gastrointest Liver Physiol. 2000; 279:G1274-G1281. [PubMed: 11093951]

29. Yang S, Zhou M, Chaudry IH, Wang P. Norepinephrine-induced hepatocellular dysfunction in early sepsis is mediated by activation of alpha2-adrenoceptors. Am J Physiol Gastrointest Liver Physiol. 2001; 281:G1014-G1021. [PubMed: 11557522]

30. Zanotti-Cavazzoni SL, Hollenberg SM. Cardiac dysfunction in severe sepsis and septic shock. Curr Opin Crit Care. 2009; 15:392-397. [PubMed: 19633546]

31. El-Menyar AA, Davidson BL. Clinical implications of cytokines in the critical-care unit. Expert Rev Cardiovasc Ther. 2009; 7:835-845. [PubMed: 19589119] 
32. Bhatia M, Moochhala S. Role of inflammatory mediators in the pathophysiology of acute respiratory distress syndrome. J Pathol. 2004; 202:145-156. [PubMed: 14743496]

33. Koo DJ, Chaudry IH, Wang P. Kupffer cells are responsible for producing inflammatory cytokines and hepatocellular dysfunction during early sepsis. J Surg Res. 1999; 83:151-157. [PubMed: 10329110]

34. Wichterman KA, Baue AE, Chaudry IH. Sepsis and septic shock: a review of laboratory models and a proposal. J Surg Res. 1980; 29:189-201. [PubMed: 6997619]

35. Yang S, Cioffi WG, Bland KI, Chaudry IH, Wang P. Differential alterations in systemic and regional oxygen delivery and consumption during the early and late stages of sepsis. $\mathrm{J}$ Trauma. 1999; 47:706-712. [PubMed: 10528605]

36. Koo DJ, Zhou M, Jackman D, Cioffi WG, Bland KI, Chaudry IH, Wang P. Is gut the major source of proinflammatory cytokine release during polymicrobial sepsis? Biochim Biophys Acta. 1999; 1454:289-295. [PubMed: 10452963] 


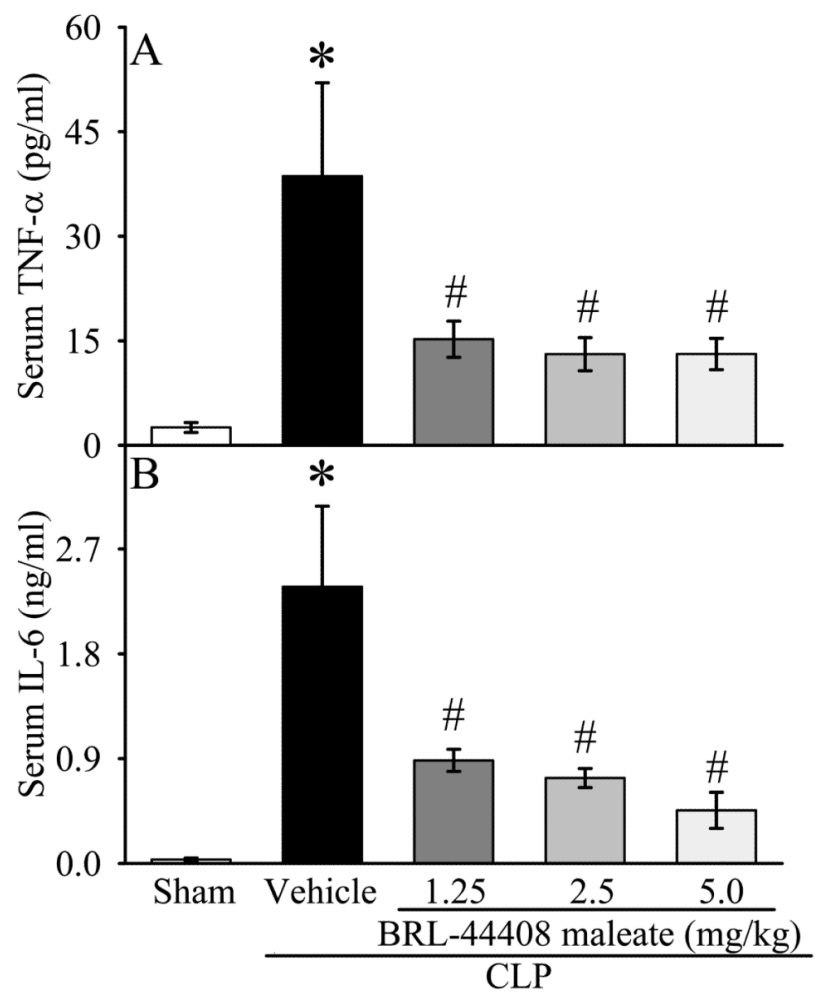

Figure 1.

Alterations in serum levels of (A) TNF- $\alpha$ and (B) IL-6 in sham-operated animals (Sham) and septic animals treated with normal saline (Vehicle) or BRL 44408 maleate $(1.25 \mathrm{mg} / \mathrm{kg} \mathrm{BW}$, $2.5 \mathrm{mg} / \mathrm{kg} \mathrm{BW}$, or $5.0 \mathrm{mg} / \mathrm{kg} \mathrm{BW}$ ) at $20 \mathrm{~h}$ after cecal ligation and puncture (CLP). Data are presented as means $\pm \mathrm{SE}(\mathrm{n}=6$ /group $)$ and compared by one-way analysis of variance and Student-Newman-Keuls' test: $* P<0.05$ vs. sham group; $\# P<0.05$ vs. vehicle group. 


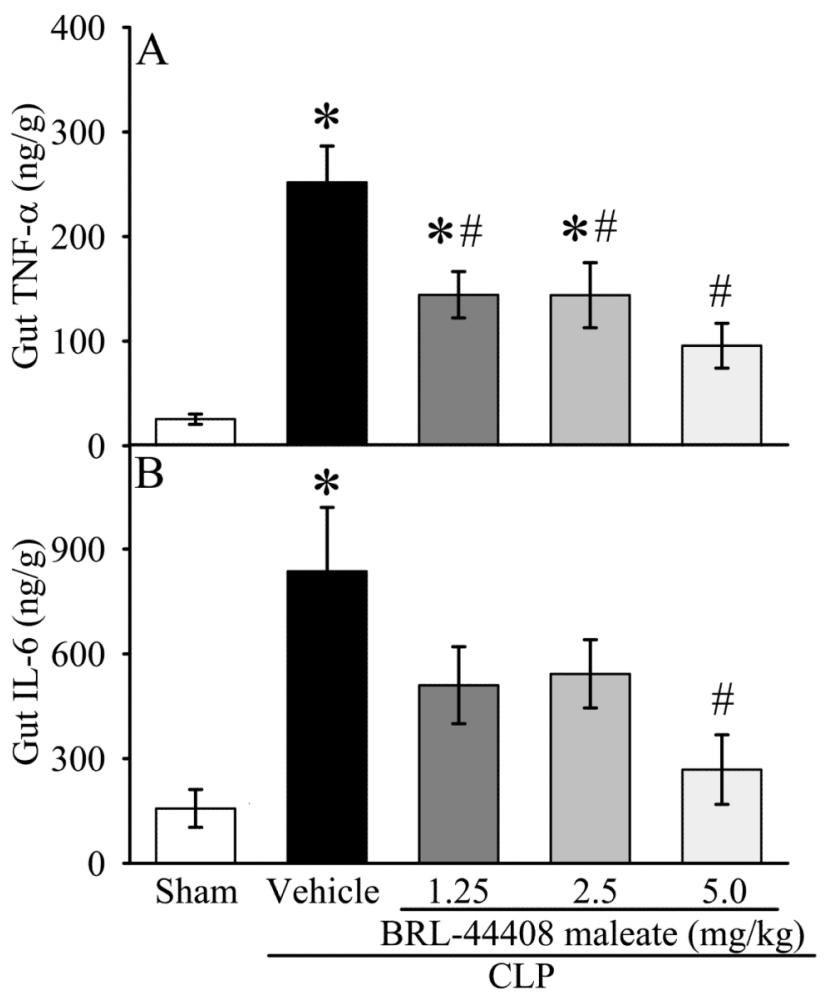

Figure 2.

Alterations in intestinal levels of (A) TNF- $\alpha$ and (B) IL-6 in sham-operated animals (Sham) and septic animals treated with normal saline (Vehicle) or BRL 44408 maleate $(1.25 \mathrm{mg} / \mathrm{kg}$ $\mathrm{BW}, 2.5 \mathrm{mg} / \mathrm{kg} \mathrm{BW}$, or $5.0 \mathrm{mg} / \mathrm{kg} \mathrm{BW}$ ) at $20 \mathrm{~h}$ after cecal ligation and puncture (CLP). Data are presented as means \pm SE $(n=6 /$ group) and compared by one-way analysis of variance and Student-Newman-Keuls' test: $* P<0.05$ vs. sham group; $\# P<0.05$ vs. vehicle group. 


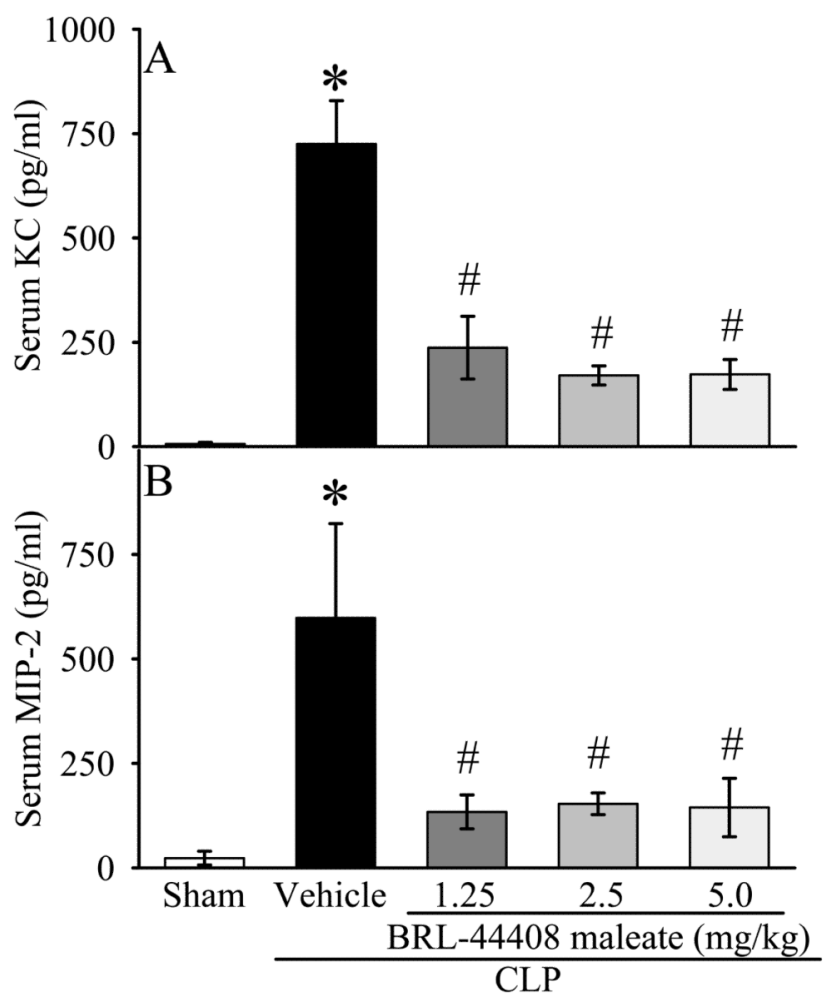

Figure 3.

Alterations in serum levels of (A) keratinocyte-derived chemokine (KC) and (B) macrophage inflammatory protein-2 (MIP-2) in sham-operated animals (Sham) and septic animals treated with normal saline (Vehicle) or BRL 44408 maleate $(1.25 \mathrm{mg} / \mathrm{kg} \mathrm{BW}, 2.5$ $\mathrm{mg} / \mathrm{kg} \mathrm{BW}$, or $5.0 \mathrm{mg} / \mathrm{kg} \mathrm{BW}$ ) at $20 \mathrm{~h}$ after cecal ligation and puncture (CLP). Data are presented as means \pm SE $(n=6 /$ group $)$ and compared by one-way analysis of variance and Student-Newman-Keuls' test: ${ }^{*} P<0.05$ vs. sham group; $\# P<0.05$ vs. vehicle group. 


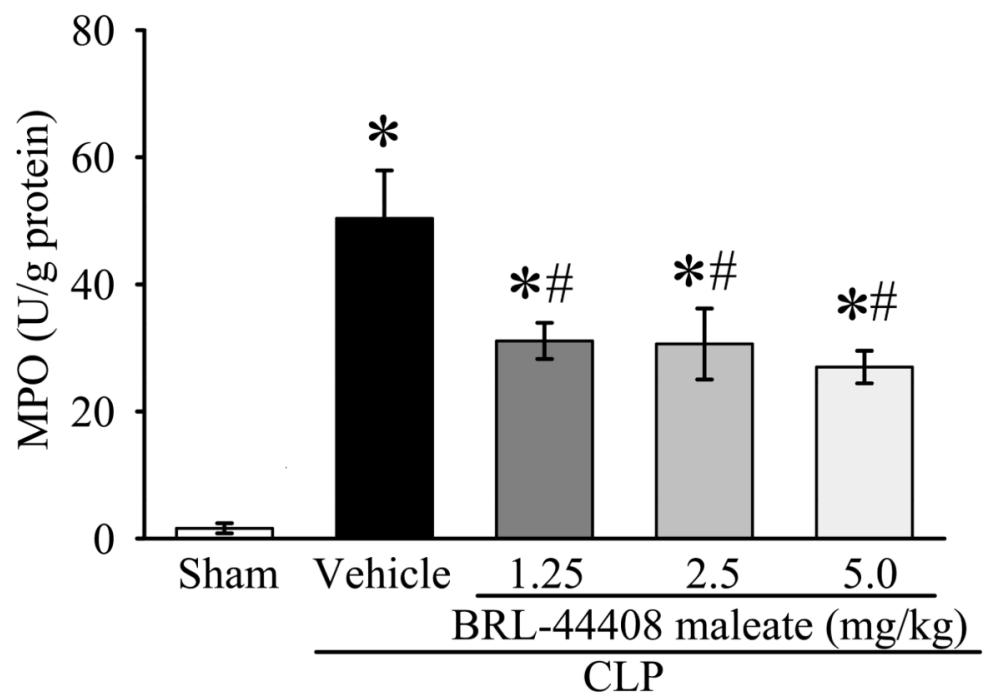

Figure 4.

Alterations in MPO activity in the gut in sham-operated animals (Sham) and septic animals treated with normal saline (Vehicle) or BRL 44408 maleate $(1.25 \mathrm{mg} / \mathrm{kg} \mathrm{BW}, 2.5 \mathrm{mg} / \mathrm{kg}$ $\mathrm{BW}$, or $5.0 \mathrm{mg} / \mathrm{kg} \mathrm{BW}$ ) at $20 \mathrm{~h}$ after cecal ligation and puncture (CLP). Data are presented as means $\pm \mathrm{SE}(\mathrm{n}=6$ /group) and compared by one-way analysis of variance and StudentNewman-Keuls' test: $* P<0.05$ vs. sham group; $\# P<0.05$ vs. vehicle group. 


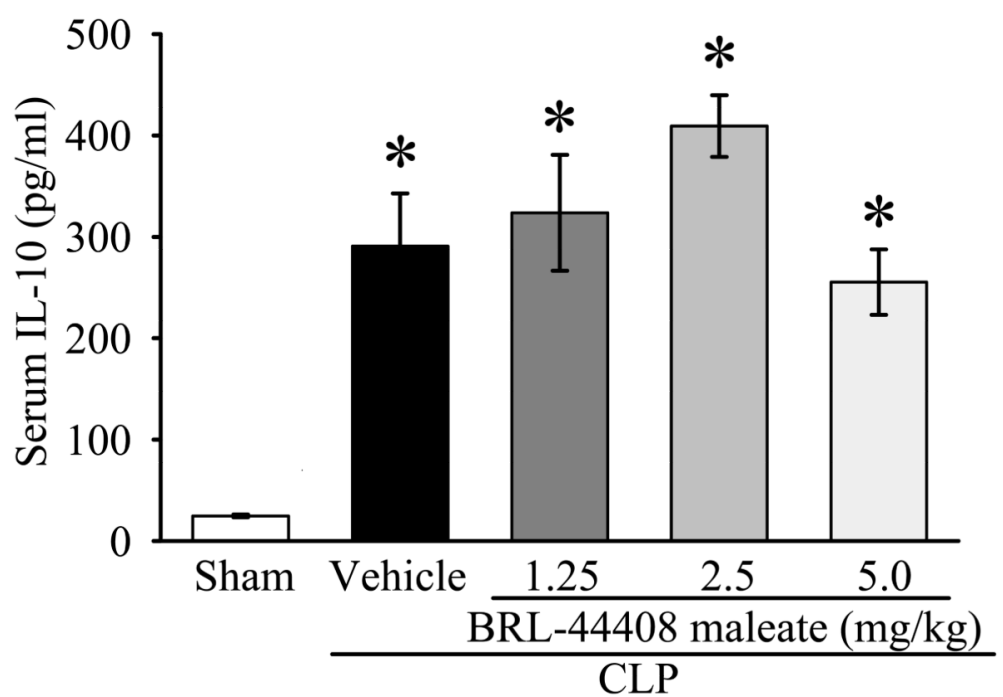

Figure 5.

Alterations in serum levels of IL-10 in sham-operated animals (Sham) and septic animals treated with normal saline (Vehicle) or BRL 44408 maleate $(1.25 \mathrm{mg} / \mathrm{kg} \mathrm{BW}, 2.5 \mathrm{mg} / \mathrm{kg}$ $\mathrm{BW}$, or $5.0 \mathrm{mg} / \mathrm{kg} \mathrm{BW}$ ) at $20 \mathrm{~h}$ after cecal ligation and puncture (CLP). Data are presented as means $\pm \mathrm{SE}$ ( $n=6$ /group) and compared by one-way analysis of variance and StudentNewman-Keuls' test: $* P<0.05$ vs. sham group. 


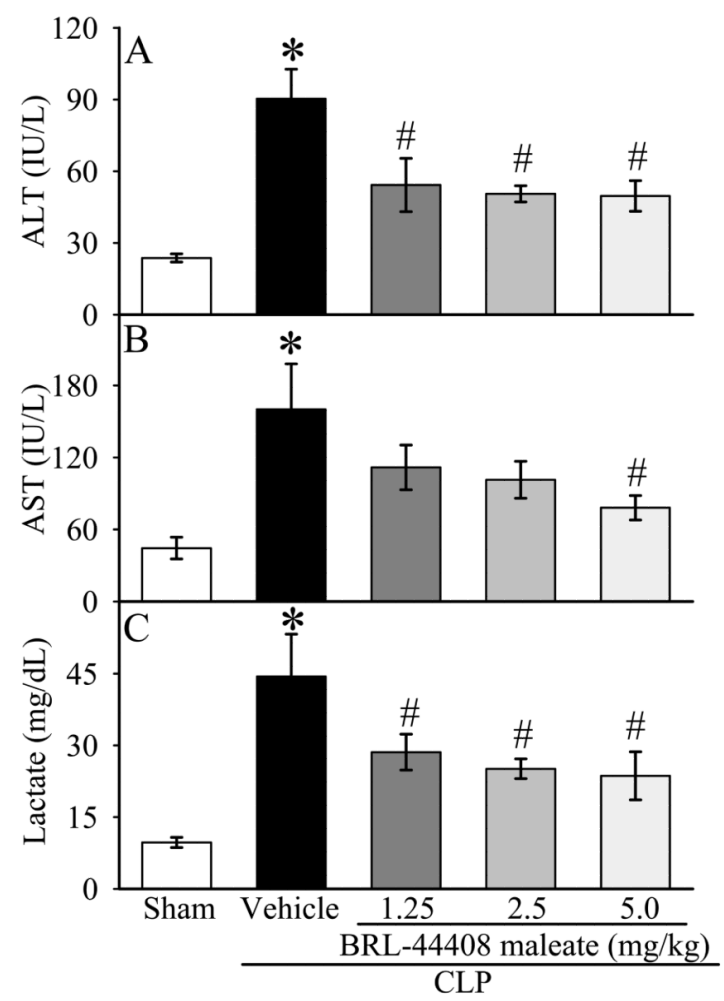

Figure 6.

Alterations in circulating levels of (A) alanine aminotransferase (ALT), (B) aspartate aminotransferase (AST), and (C) lactate in sham-operated animals (Sham) and septic animals treated with normal saline (Vehicle) or BRL 44408 maleate $(1.25 \mathrm{mg} / \mathrm{kg} \mathrm{BW}, 2.5$ $\mathrm{mg} / \mathrm{kg} \mathrm{BW}$, or $5.0 \mathrm{mg} / \mathrm{kg} \mathrm{BW}$ ) at $20 \mathrm{~h}$ after cecal ligation and puncture (CLP). Data are presented as means \pm SE ( $n=6$ /group) and compared by one-way analysis of variance and Student-Newman-Keuls' test: $* P<0.05$ vs. sham group; $\# P<0.05$ vs. vehicle group. 


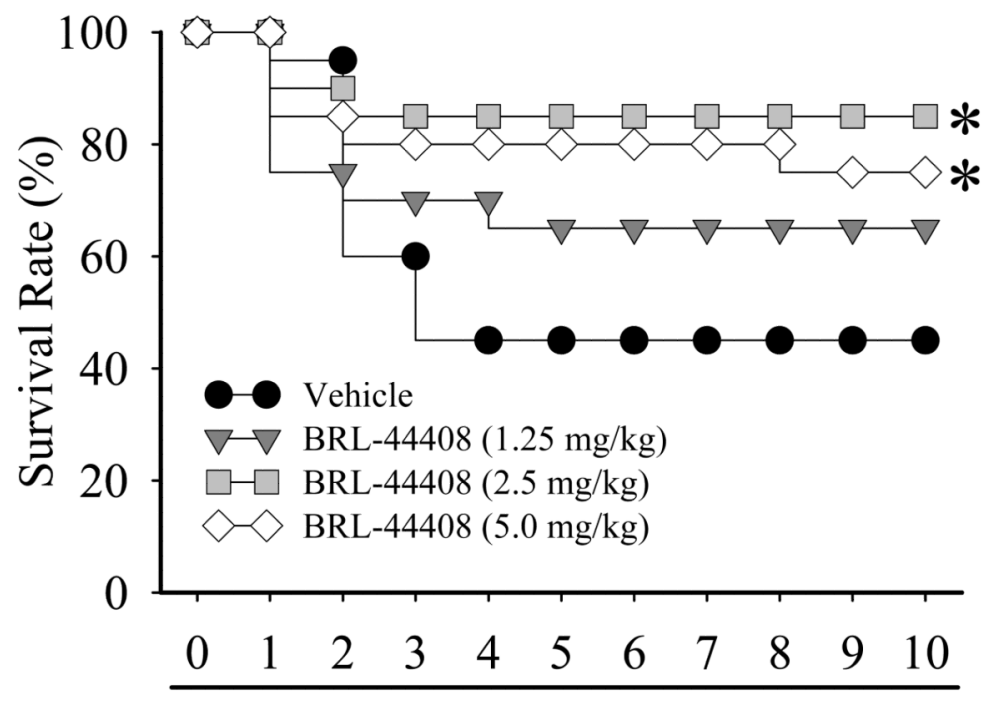

Days after CLPE

Figure 7.

Alterations in the survival rate at 10 days after cecal ligation and puncture and cecal excision with normal saline treatment (CLPE+Vehicle) or BRL 44408 maleate $(1.25 \mathrm{mg} / \mathrm{kg} \mathrm{BW}, 2.5$ $\mathrm{mg} / \mathrm{kg} \mathrm{BW}$, or $5.0 \mathrm{mg} / \mathrm{kg} \mathrm{BW}$ ) treatment. There were 20 animals in each group. The survival rates were estimated by the Kaplan-Meier method and compared by using the log-rank test. $* P<0.05$ vs. vehicle group. 


\section{Table 1}

Effects of lower doses of BRL 44408 maleate on serum levels of TNF- $\alpha$, IL-6, IL-10, AST, Lactate and gut MPO activity at $20 \mathrm{~h}$ after cecal ligation and puncture (CLP).

\begin{tabular}{lllll}
\hline & Sham & CLP-Vehicle & \multicolumn{2}{c}{$\begin{array}{c}\text { CLP-BRL 44408 maleate } \\
(\mathbf{m g} / \mathbf{k g ~ B W})\end{array}$} \\
\cline { 4 - 5 } & & & $\mathbf{0 . 3 1 2 5}$ & $\mathbf{0 . 6 2 5}$ \\
\hline TNF- $\alpha(\mathrm{pg} / \mathrm{ml})$ & $3.3 \pm 2.2$ & $34.4 \pm 3.0^{*}$ & $30.5 \pm 11.0^{*}$ & $22.6 \pm 6.3$ \\
IL-6 $(\mathrm{ng} / \mathrm{ml})$ & $0.05 \pm 0.02$ & $2.35 \pm 0.20^{*}$ & $1.71 \pm 0.21^{*}$ & $1.26 \pm 0.56^{*}$ \\
\hline IL-10 $(\mathrm{pg} / \mathrm{ml})$ & $24.8 \pm 1.4$ & $290.8 \pm 52.0^{*}$ & $358.9 \pm 125.8^{*}$ & $338.0 \pm 23.9^{*}$ \\
\hline AST (IU/L) & $44.3 \pm 10.6$ & $141.6 \pm 21.0$ & $105.1 \pm 6.1^{*}$ & $111.9 \pm 11.1^{*}$ \\
\hline Lactate (mg/dl) & $12.7 \pm 1.4$ & $44.3 \pm 6.3^{*}$ & $38.6 \pm 8.5$ & $29.9 \pm 3.9$ \\
\hline Gut MPO (U/g protein) & $5.2 \pm 1.1$ & $54.6 \pm 16.8^{*}$ & $48.3 \pm 8.1^{*}$ & $42.9 \pm 8.2^{*}$ \\
\hline
\end{tabular}

Data are expressed as means \pm SE ( $n=5-6 /$ group) and compared by one-way analysis of variance (ANOVA) and Student-Newman-Keuls method: ${ }^{*} P<0.05$ versus sham-operated animals. 